\title{
Effective Dose of Rosella Calyx Extract (Hibiscus sabdariffa L.) against Liver Marker Enzymes and Liver Histopathological of High-Fat Feed-Induced Rats
}

\author{
Meilinah Hidayat*, Oeij A Adhika**, Fenny Tanuwijaya***, \\ Adisurja Nugraha****, Ricky B Hutagalung **** \\ *Department of NutritionFaculty of Medicine Maranatha Christian University \\ **Department of Anatomy Faculty of Medicine Maranatha Christian University \\ ***Department of Clinical Pathology Faculty of Medicine \\ Maranatha Christian University \\ **** Faculty of Medicine Maranatha Christian University \\ Jl. Prof. drg. Suria Sumantri MPH No.65 Bandung 40164 Jawa Barat Indonesia
}

Email: mellahidayat@yahoo.com

\begin{abstract}
Liver disease is a disease caused by various factors that damage the liver, such as viruses, obesity and alcohol consumption. Many studies have been done to find natural remedies for this disease, one of which is Rosella. In this research, the effective dose of ethanol extract of rosella calyx (EERC) was conducted, in high-fat feed (HFF)-induced rats. The aim of this study was to determine the effective dose of EEKR based on parameters:liver histopathological, Alanine Transferase (ALT) and Gamma Glutamyl Transferase (GGT) level. The study was conducted on 30 male Wistar rats, which were divided into five treatment groups. As results, histopathological observations showed a significant decrease in cloudy swelling scores at EERC $200 \mathrm{mg} / \mathrm{KgBW} / \mathrm{d}$, decreased steatosis scores at doses of 200, 400, $600 \mathrm{mg}$; whereas ballooning degeneration, lobular inflammation, and fibrosis scores did not decrease. EERC 200, 400, $600 \mathrm{mg} / \mathrm{KgBW} / \mathrm{d}$ significantly decreased ALT $(p \leq 0.01)$; while doses of 400 and $600 \mathrm{mg}$ reduce GGT. Conclusions, effective dose of EEKR for liver disease based on histopathological features of liver, ALT and GGT in HFF-induced Wistar rats is dose of 200 $400 \mathrm{mg} / \mathrm{KgBW} / \mathrm{day}$.
\end{abstract}

Keywords: effective dose, Rosella, histopathologic, Alanine Transferase, Gamma Glutamyl Transferase 


\title{
Dosis Efektif Ekstrak Kelopak Bunga Rosella (Hibiscus sabdariffa L.) terhadap Enzim Hati dan Histopatologis Tikus yang Diinduksi Pakan Tinggi Lemak
}

\author{
Meilinah Hidayat*, Oeij A Adhika**, Fenny Tanuwijaya***, \\ Adisurja Nugraha****, Ricky B Hutagalung**** \\ *Bagian Gizi Fakultas Kedokteran Universitas Kristen Maranatha \\ **Bagian Anatomi Fakultas Kedokteran Universitas Kristen Maranatha \\ ***Bagian Patologi Klinik Fakultas Kedokteran Universitas Kristen Maranatha \\ **** Fakultas Kedokteran Universitas Kristen Maranatha \\ Jl. Prof. drg. Suria Sumantri MPH No.65 Bandung 40164 Jawa Barat Indonesia \\ Email: mellahidayat@yahoo.com
}

\begin{abstract}
Abstrak
Penyakit hati adalah penyakit yangdisebabkan oleh berbagai faktor yang merusak hati, seperti virus, obesitas dan penggunaan alkohol.Telah banyak dilakukan penelitian untuk mendapatkan obat alami untuk penyakit ini, salah satunya adalah Rosella. Dalam penelitian ini dilakukan penelitian efek ekstrak etanol kelopak rosella (EEKR), berdasarkan histopatologis dan enzim hati tikus yang diinduksi pakan tinggi lemak (PTL). Tujuan Penelitian adalahmenentukan dosis efektif EEKR untuk penyakit hati berdasarkan gambaran histopatologi hati, Alanine Transferase (ALT) dan Gamma Glutamyl Transferase (GGT). Penelitian dilakukan pada 30 tikus Wistar jantan, yang dibagi menjadi lima kelompok perlakuan. Parameter yang diukur adalahgambaran histopatologis hati, yang dinilai dengan sistem skor dan kadar ALT \& GGT serum. Hasil pengamatan histopatologis menunjukkan penurunan paling besar skor bengkak keruh pada EEKR dosis $200 \mathrm{mg} / \mathrm{KgBB} / \mathrm{hr}$, penurunan skor steatosis pada dosis 200, 400, $600 \mathrm{mg} / \mathrm{KgBB} / \mathrm{hr}$; sedangkan skor degenerasi balon, peradangan lobular, dan fibrosis tidak menurun. EEKR 200, 400, $600 \mathrm{mg} / \mathrm{KgBB} / \mathrm{hr}$ signifikan menurunkan ALT ( $\mathrm{p} \leq$ 0,01 ); sedangkan dosis 400dan $600 \mathrm{mg} / \mathrm{KgBB} / \mathrm{hr}$ menurunkan GGT. Simpulan, dosis efektif EEKR untuk penyakit hati berdasarkan gambaran histopatologis hati, ALT dan GGT pada tikus Wistar jantan yang diinduksi oleh PTL adalah dosis $200-400 \mathrm{mg} / \mathrm{KgBB} / \mathrm{hr}$.
\end{abstract}

Kata kunci: dosis efektif, Rosella, gambaran histopatologis, ALT, GGT 


\section{Research Article}

\section{Pendahuluan}

Penyakithati adalah penyakit yang disebabkan oleh berbagai faktor yang merusak hati, seperti virus, obesitas dan penggunaan alkohol. Pada kondisi hati yang rusak dikeluarkan banyak radikal bebas yang akhirnya menyebabkan keadaan stres oksidatif. Stres oksidatifadalah suatu kondisi di mana produksi radikal bebas lebih tinggi dari tingkat antioksidan dalam tubuh sehingga menyebabkan berbagaifungsi tubuh terganggu, misalnya organ hati. ${ }^{1}$ Stres oksidatif dapat dihambat oleh antioksidan yang terdapat pada berbagai sumber alami. Telah banyak dilakukan penelitian untuk mendapatkan obat alami untuk penyakit hati, salah satunya adalah Rosella. Bunga Rosella (Hibiscus sabdariffa L.), diketahui memiliki kandungan antioksidan yang tinggi. ${ }^{1,2,3}$ Kandungan antioksidan dalam Rosella memiliki efek pemerangkapan radikal bebas yang baik sehingga mampu melindungi sel hepatosit dari kerusakan yang disebabkan oleh peroksidasi lemak. $^{4,5}$

Stres oksidatif dianggap sebagai mekanisme patologis yang berkontribusi terhadap inisiasi dan pengembangan kerusakan hati. ${ }^{6}$ Asupan lemak yang berlebihan mengarah pada pembentukan spesies oksigen reaktif/Reactive Oxygen Species (ROS), yang pada gilirannya menyebabkan peroksidasi lipid pada membran sel hepatosit. Proses inimenyebabkan kerusakan struktural hepatosit dalam bentuk pembengkakan keruh, steatosis, peradangan lobular, degenerasi balon, dan fibrosis. ${ }^{7}$

Di Indonesia, banyak terdapat penderita penyakit perlemakan hati nonalkohol atau NonAlcohol Fatty Liver Disease(NAFLD) dengan akumulasi berlebih sel lemak karena asupan trigliserida yang tinggi, terutama dari kebiasaan konsumsi diet aterogenik berlebihan. Penyakit NAFLDdisebabkan akumulasi lemak berlebih dalam sel hati untuk jangka waktu yang lama. ${ }^{8.9}$ Penyakit hati ini selanjutnya berkembang menjadi stadium yang lebih parah, ditandai dengan adanya bentuk steatosis pada hati tanpa riwayat penggunaan alkohol yang signifikan atau penyakit hati lainnya, dikenal dengan istilah Non-Alcohol Steato Hepatitis (NASH). ${ }^{10}$

Steatosis, peradangan lobular, fibrosis dan pembengkakan hepatoseluler adalah gambaranhistopatologis yang mutlak diperlukan untuk mendiagnosis NASH; pemeriksaan histopatologis spesimen biopsi, tetap menjadi baku emas untuk standar diagnosis NAFLD/NASH. ${ }^{11}$ Sedangkan parameter kimia klinik yang digunakan sebagai penanda kerusakan hati adalah enzim Alanine Transferase (ALT) and Gamma Glutamyl Transferase (GGT).Aktivitas serum ALT dianggap sebagai penanda penyakit hati yang sensitif dan handal. Fungsi utama ALT adalah sebagai enzim yang mengkatalisasi transfer kelompok amino untuk membentuk metabolit hati oksaloasetat. Dalam kasus cedera hepatoseluler atau kematian sel hati, pelepasan ALT dari sel hati yang rusak meningkatkan aktivitas ALT yang diukur dalam 


\section{Research Article}

serum. Pada kondisi NASH ditemukan kadar ALT sangat tinggi dalam sitosol hepatosit.Kadar enzim ALT dalam serum darah pada keadaan normal seharusnya rendah. Enzim ALT ini lebih spesifik memprediksi penyakit hati daripada Aspartate Aminotransferase (AST). ${ }^{12}$

Parameter yang lain, yaitu enzim GGT,dibentuk pada retikulum endoplasma dan sel-sel epitel empedu dan kadarnya meningkat pada semua jenis penyakit hati. ${ }^{13}$ Enzim GGT ini merupakan faktor penting, untuk menentukan Algoritma Indeks Lemak Hati / Fat Liver Index (FLI), selain Indeks Massa Tubuh (IMT), lingkar pinggang, dan kadar trigliserida. Algoritma FLImemiliki akurasi tinggi dalam mendeteksi kondisi hati berlemak [0,84 (95\% CI 0,81$0,87)] \cdot{ }^{14}$

Penelitian Ali dkk menunjukkan bahwa ekstrak air Hibiscus sabdariffa yang diberikan selama 4 minggu dengan dosis $200 \mathrm{mg} / \mathrm{kgBB}$ pada tikus yang diinduksi parasetamol $(700 \mathrm{mg}$ /KgBB), mampu berfungsi sebagai pelindung hati. ${ }^{15}$ Penelitian Sujono dkk yang menggunakan ekstrak infus Rosella dengan konsentrasi 20\% (2,5g/KgBB) dan $40 \%(5 \mathrm{~g} / \mathrm{KgBB})$ selama 7 hari pada tikus yang diinduksi zat toksikparacetamol-dosis $(2,5 \mathrm{~g} / \mathrm{KgBB})$ menurunkan kadar enzim ALT secara signifikan. ${ }^{16}$ Ekstrak bunga rosella kering dosis $100 \mathrm{mg} / \mathrm{kgBB}$ dua kali sehari terbukti menunjukkan efek perlindungan hati pada tikus yang diinduksi dengan 2,4dinitrophenylhydrazine (2,4-DNPH). Ekstrak Rosella secara signifikan menurunkan kadar enzim hati seperti ALT dan AST serta mengurangi kerusakan hati. ${ }^{17}$

Penelitian di Jepang dan Amerika tahun 2006 membuktikan bahwa bunga Rosella (Hibiscus sabdariffa) mengandung antioksidan Antosianin yang tinggi. Antosianin yang berwarna merah ini mempunyai potensi menurunkan stres oksidatif dan digunakan sebagai hepatoprotektor. ${ }^{18}$ Mekanisme antioksidan dalam menurunkan stres oksidatif dan disfungsi mitokondria adalah dengan cara menurunkan ekspresi $\mathrm{Bcl}$ 2-assosiated-x protein (Bax) dan truncated Bcl2 Interacting Domain (tBID) pada hati. ${ }^{19}$

Telah banyak dilakukan penelitian terhadap Rosella ini, namun dosis dan jenis ekstrak yang digunakan berbeda-beda. Tujuan penelitian ini adalah menetapkan dosis efektif EEKR untuk penyakit hati berdasarkan gambaran histopatologis hati, Alanine Transferase (ALT) dan Gamma Glutamyl Transferase (GGT).

\section{Metode}

Alat yang digunakan adalah kandang tikus, tempat makan dan minum tikus, timbangan digital, alat pembuat pakan tikus, sonde oral, alat pengukur kadar enzim hatiALT dan GGT, Roche Cobas C311. Bahan yang digunakan adalah: Kelopak bunga rosella kering (Hibiscus 


\section{Research Article}

sabdariffa L.) yang diperoleh dari desa Ngingas, Jawa Tengah. Ekstrak kelopak bunga Rosellayang diperoleh dengan cara maserasi sederhana menggunakan etanol $90 \%$, pelet standar, akuades, pakan tinggi lemak yang terdiri dari $8 \mathrm{~kg}$ pelet standar, 15 butir kuning telur bebek, 2,5 $\mathrm{kg}$ terigu, $3 / 4 \mathrm{~kg}$ minyak kelapa, $1 \mathrm{~kg}$ lemak kambing, air panas secukupnya.Objek penelitian adalah tikus Wistar jantan berusia 6 minggu dengan bobot badan 200-250 gram yang diperoleh dari Laboratorium Farmakologi Rumah Sakit Hasan Sadikin Bandung, dengan kriteria: jenis kelamin jantan, galur Wistar, usia 6 minggu, bobot badan 200-250 g. ${ }^{20}$

Objek penelitian yaitu tikus Wistar jantan sebanyak 30 ekor, dibagi ke dalam 5 kelompok secara acak dan masing-masing kelompok terdiri dari 6 ekor. Tikus diadaptasikan di Laboratorium Farmakologi Rumah Sakit Hasan Sadikin Bandung selama 7 hari.

Prosedur kerja penelitian sebagai berikut:Kelompok 1. Kontrol Negatif $(\mathrm{KN})$ diberi makan pakan Standar selama 50 hari, 2. Kontrol Pakan Tinggi Lemak (PTL): diberikan PTL selama 50 hari, kelompok 3.P1: PTL 50 hari, pada hari ke 22 hingga 50 diberi dosis EEKR 200 $\mathrm{mg} / \mathrm{KgBB} / \mathrm{hr}$, 4. Kelompok P2: PTL 50 hari, pada hari ke 22 hingga 50 diberi dosis EEKR 400mg/KgBB/hr, 5. Kelompok P3: PTL 50 hari, pada hari ke 22 hingga 50 diberi dosis EEKR $600 \mathrm{mg} / \mathrm{KgBB} / \mathrm{hr}$. Penelitian ini telah mendapat persetujuan dari Komite Etik Universitas Kristen Maranatha Bandung (003 / KEP FK UKM-RSI / IV / 2015). Pada hari ke 50 semua tikus dibunuh, dan diambil organ hatinya untuk dibuat preparat histopatologis. Kadar ALT dan GGT diukur pada awal penelitian, hari ke 22 dan ke 50 penelitian.

Preparat hati tikus yangtelah diwarnai Haematoxylin-Eosin dinilai melalui pengamatan di bawah mikroskop cahaya dengan perbesaran 100 kali. Skor analisis histopatologis hati diperoleh dari pengamatan di 10 bidang lapang pandang, selanjutnya dihitungrerata skor dari setiap parameter yang diamati (bengkak keruh, steatosis, peradangan lobular, degenerasi balon, dan fibrosis).Skor gambaran histopatologis berdasarkan kriteria penilaian berikut.

Analisis histopatologis bengkak keruh hepar tikus dilakukan dengan menggunakan penilaian: ${ }^{21}$

- Skor 0: normal tidak dijumpai kerusakan yang diamati.

- Skor 1: apabila dalam suatu lapang pandang dijumpai kerusakan kurang dari sepertiga bagian yang diamati (kerusakan ringan).

- Skor 2: apabila dalam suatu lapang pandang dijumpai kerusakan lebih dari sepertiga sampai dengan dua pertiga bagian yang diamati (kerusakan sedang).

- Skor 3: apabila dalam suatu lapang pandang dijumpai kerusakan lebih dari dua pertiga sampai dengan seluruh bagian yang diamati hilang (kerusakan berat). 


\section{Research Article}

Analisis histopatologis steatosis hepar tikus dilakukan dengan penilaian: ${ }^{9}$

- Skor 0: terdapat gambaran kurang dari 5\% hepatosit yang mengalami steatosis.

- Skor 1: terdapat gambaran 5-33\% hepatosit yang mengalami steatosis.

- Skor 2: terdapat gambaran 33-66\% hepatosit yang mengalami steatosis.

- Skor 3: terdapat gambaran lebih dari 66\% hepatosit yang mengalami steatisis .

Analisis histopatologis inflamasi lobular hepar tikus dilakukan dengan penilaian: ${ }^{21}$

- Skor 0: tidak ditemukan adanya fokus inflamasi.

- Skor 1: ditemukan satu sampai dua fokus inflamasi per sepuluh lapang pandang.

- Skor 2: ditemukan dua sampai empat fokus inflamasi per sepuluh lapang pandang.

- Skor 3: ditemukan lebih dari empat fokus inflamasi per sepuluh lapang pandang. Analisis histopatologis degenerasi balon hepar tikus dilakukan penilaian: ${ }^{21}$

- Skor 0: tidak ditemukan adanya degenerasi balon.

- Skor 1: ditemukan sedikit degenerasi balon.

- Skor 2: ditemukan banyak degenerasi balon.

Analisis histopatologis fibrosis lobular hepar tikus dilakukan penilaian: ${ }^{21}$

- Skor 0: pada gambaran mikroskopis tidak ditemukan adanya gambaran fibrosis.

- Skor 1: pada gambaran mikroskopis ditemukan gambaran perisinusoidal atau periportal fibrosis.

- Skor 2: pada gambaran mikroskopis ditemukan gambaran fibrosis di daerah perisinusoidal dan portal atau periportal fibrosis.

- Skor 3: pada gambaran mikroskopis ditemukan adanya gambaran bridging fibrosis.

- Skor 4: pada gambaran mikroskopis ditemukan gambaran sirosis.

Hasil rerata skor preparat histopatologi dianalisis menggunakan uji statistik KruskalWallis, dilanjutkan dengan post hoc test Mann-Whitney untuk mengetahui perbedaan dari tiap kelompok perlakuan.Data ALT dan GGT dianalisis menggunakan ANAVA dengan batas kemaknaan $\alpha<0,05$ dan tingkat kepercayaan 95\%, dilanjutkan dengan uji beda rata-rata Fisher LSD untuk mengetahui kelompok mana yang berbeda.

\section{Hasil}

\section{Hasil Rerata Skor dari Pengamatan Histopatologis}




\section{Research Article}

Hasil analisis gambaran bengkak keruh pada kelompok perlakuan Rosella 200mg/kgBB/hr menunjukkan hasil yang berbeda signifikan bila dibandingkan dengan kelompok kontrol PTL. Hasil dapat dilihat pada tabel 1 dan Gambar 1 hingga 5.

Tabel 1 Analisis Statistik Mann-Whitney dari Rerata Skor Bengkak Keruh

\begin{tabular}{cccccc}
\hline Kelompok & Kontrol (-) & PTL & P1 & P2 & P3 \\
\hline Kontrol (-) & & $0,004^{* *}$ & $0,65^{\text {ns }}$ & $0,009^{* *}$ & $0,002^{* *}$ \\
PTL & & & $0,041^{*}$ & $0,180^{\text {ns }}$ & $0,132^{\text {ns }}$ \\
P1 & & & & $0,394^{\text {ns }}$ & $0,002^{* *}$ \\
P2 & & & & & $0,009^{* *}$ \\
P3 & & & & \\
\hline
\end{tabular}

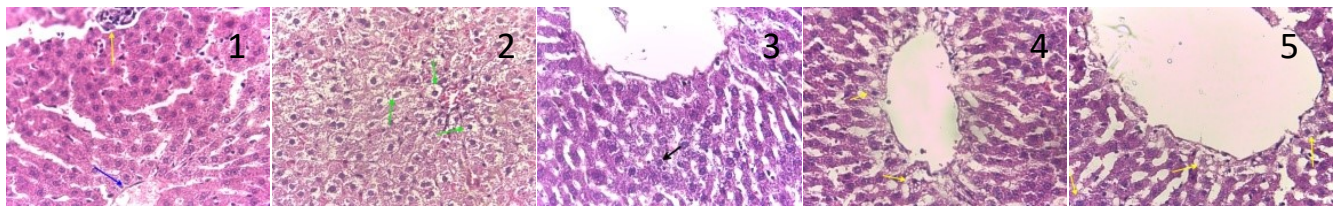

Gambar 1 Hepar dari kelompok kontrol negatif tidak menunjukkan gambaran bengkak keruh. Tanda panah biru menunjukkan Vena centralis dan tanda panah kuning menunjukkan trias hepatica (400x).

Gambar 2 Hepar dari kelompok kontrol PTL menunjukkan gambaran bengkak keruh, berupa hepatosit membesar, sitoplasma bergranul, dan lebih opak dari hepatosit normal dengan kerusakan sedang(400x).

Gambar 3 Hepar dari kelompok rosela 200 mg menunjukkan gambaran bengkak keruh, berupa hepatosit membesar, sitoplasma lebih bergranul, dan lebih opak dari hepatosit normal. Gambaran bengkak keruh yang ditunjukkan tanda panah hitam memperlihatkan kerusakan yang ringan $(400 \mathrm{x})$.

Gambar 4 Hepar dari kelompok rosela 400 mg menunjukkan gambaran bengkak keruh, berupa hepatosit membesar, sitoplasma lebih bergranul, dan lebih opak dari hepatosit normal. Gambaran bengkak keruh yang ditunjukkan tanda panah kuning memperlihatkan kerusakan yang ringan (400x).

Gambar 5 Hepar dari kelompok rosela 600 mg menunjukkan gambaran bengkak keruh, berupa hepatosit membesar, sitoplasma lebih bergranul, dan lebih opak dari hepatosit normal. Gambaran bengkak keruh yang ditunjukkan tanda panah kuning memperlihatkan kerusakan yang sedang (400x).

Hasil analisis gambaran steatosis, pemberian EEKR $200 \mathrm{mg}, 400 \mathrm{mg}$, dan $600 \mathrm{mg}$ menunjukkan hasil penurunan skor histopatologis steatosis yang berbeda signifikan apabila dibandingkan dengan kelompok kontrol PTL. Hasil dapat dilihat pada tabel 2 dan Gambar 6 hingga 10.

Tabel 2 Analisis Statistik Mann-Whitney dari Rerata Skor Steatosis

\begin{tabular}{cccccc}
\hline Kelompok & Kontrol (-) & PTL & P1 & P2 & P3 \\
\hline Kontrol (-) & & $0,002^{* *}$ & $0,699^{\mathrm{ns}}$ & $1,000^{\mathrm{ns}}$ & $1,000^{\mathrm{ns}}$ \\
PTL & & & $0,015^{*}$ & $0,002^{* *}$ & $0,002^{* *}$ \\
P1 & & & & $0,699^{\mathrm{ns}}$ & $0,699^{\mathrm{ns}}$ \\
P2 & & & & & $1,000^{\mathrm{ns}}$ \\
P3 & & & & & \\
\hline
\end{tabular}




\section{Research Article}

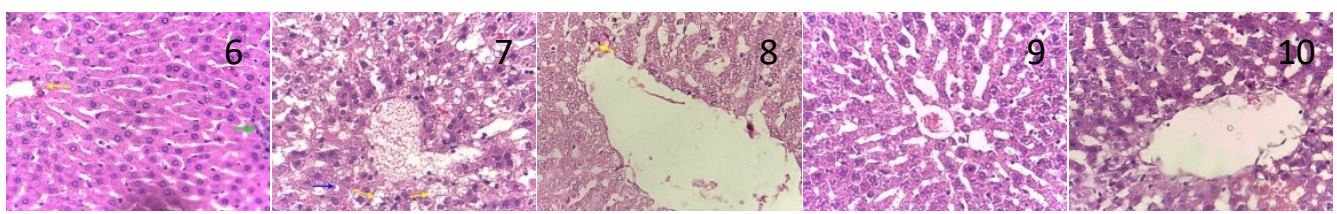

Gambar 6. Hepar dari kelompok kontrol negatif tidak menunjukkan gambaran steatosis. Tanda panah hijau menunjukkan Vena centralis dan tanda panah kuning menunjukkan Trias hepatica $(400 \mathrm{x})$.

Gambar 7 Hepar dari kelompok kontrol PTL menunjukkan gambaran steatosis. Tanda panah kuning menunjukkan gambaran fatty cyst dan tanda panah biru menunjukkan makrovesikel dimana inti terdesak oleh butiran lemak (400x).

Gambar 8 Hepar dari kelompok PTL+200 mg menunjukkan adanya gambaran steatosis. Tanda panah kuning menunjukkan gambaran makrovesikel (400x).

Gambar 9 Hepar dari kelompok PTL +400 mg tidak menunjukkan adanya gambaran steatosis (400x).

Gambar 10 Hepar dari kelompok PTL+600 mg tidak menunjukkan adanya gambaran steatosis (400x).

Hasil pengamatan gambaran peradangan lobular menunjukkan perbedaan yang signifikan pada kelompok kontrol PTL dan kelompok kontrol negatif. Hasil dapat dilihat pada tabel 3 dan Gambar 11 hingga 15.

Tabel 3 Analisis Statistik Mann-Whitney dari Rerata Skor Peradangan Lobular

\begin{tabular}{cccccc}
\hline Kelompok & Kontrol (-) & PTL & P1 & P2 & P3 \\
\hline Kontrol (-) & & $0,026^{*}$ & $0,180^{\mathrm{ns}}$ & $0,394^{\mathrm{ns}}$ & $0,093^{\mathrm{ns}}$ \\
PTL & & & $0,180^{\mathrm{ns}}$ & $0,093^{\mathrm{ns}}$ & $0,394^{\mathrm{ns}}$ \\
P1 & & & & $0,699^{\mathrm{ns}}$ & $0,699^{\mathrm{ns}}$ \\
P2 & & & & & $0,394^{\mathrm{ns}}$ \\
P3 & & & & & \\
\hline
\end{tabular}

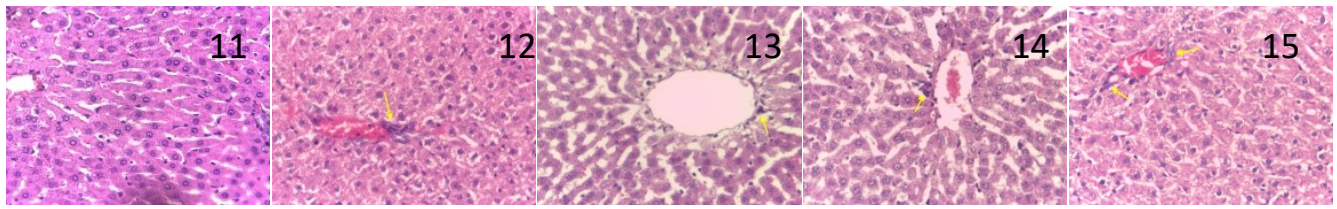

Gambar 11 Hepar dari kelompok kontrol negatif tidak menunjukkan adanya fokus inflamasi (400x).

Gambar 12 Hepar dari kelompok kontrol PTL menunjukkan adanya fokus inflamasi yang terpusat pada venae centralis (400x). Gambar 13 Hepar dari kelompok PTL+200 mg menunjukkan adanya fokus inflamasi lobular (tanda panah kuning) (400x). Gambar 14 Hepar dari kelompok PTL+400 mg menunjukkan adanya fokus inflamasi (tanda panah kuning) (400x).

Gambar 15 Hepar dari kelompok PTL+600 mg menunjukkan adanya fokus inflamasi pada zona 3 yaitu daerah venae centralis (Tanda panah kuning) (400x).

Hasil analisis gambaran degenerasi balon kelompok kontrol negatif, kontrol PTL, perlakuan Rosella 200 mg, dan perlakuan Rosella 400 mg tidak menunjukkan adanya gambaran dari degenerasi balon. Kelompok perlakuan Rosella $600 \mathrm{mg}$ menunjukkan adanya gambaran dari degenerasi balon. Hasil dapat dilihat pada tabel 4 dan Gambar 16 hingga 20. 


\section{Research Article}

\section{Tabel 4 Analisis Statistik Mann-Whitneydari Rerata Skor Degenerasi Balon}

\begin{tabular}{cccccc}
\hline Kelompok & Kontrol (-) & PTL & P1 & P2 & P3 \\
\hline Kontrol (-) & & $1,000^{\mathrm{ns}}$ & $1,000^{\mathrm{ns}}$ & $1,000^{\mathrm{ns}}$ & $0,180^{\mathrm{ns}}$ \\
PTL & & & $1,000^{\mathrm{ns}}$ & $1,000^{\mathrm{ns}}$ & $0,180^{\mathrm{ns}}$ \\
P1 & & & & $1,000^{\mathrm{ns}}$ & $0,180^{\mathrm{ns}}$ \\
P2 & & & & & $0,180^{\mathrm{ns}}$ \\
P3 & & & & & \\
\hline
\end{tabular}

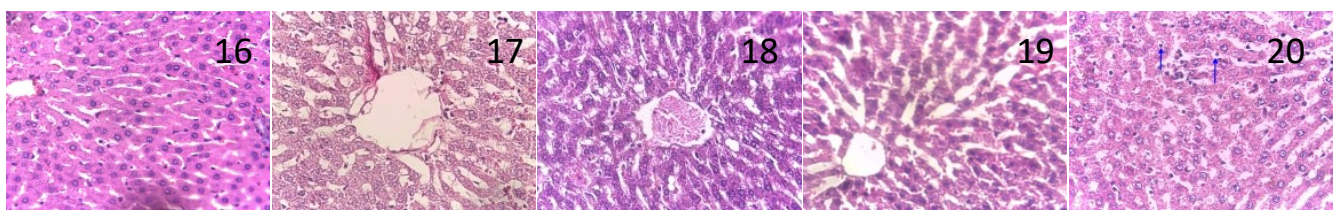

Gambar 16 Hepar dari kelompok kontrol negatif tidak menunjukkan adanya gambaran degenerasi balon (400x). Gambar 17 Hepar dari kelompok kontrol PTL tidak menunjukkan adanya gambaran degenerasi balon (400x). Gambar 18 Hepar dari kelompok PTL+200 mg tidak menunjukkan adanya gambaran degenerasi balon (400x). Gambar 19 Hepar dari kelompok PTL+400 mg tidak menunjukkan adanya gambaran degenerasi balon (400x). Gambar 20 Hepar dari kelompok PTL+600 mg menunjukkan gambaran degenerasi balon. Tanda panah biru menunjukkan hepatosit yang membengkak, dan sitoplasma jernih (400x).

Hasil analisis gambaran fibrosis didapatkan pada kelompok kontrol PTL, pemberian EEKR $200 \mathrm{mg}$, 400 mg, dan 600 mg. Hasil dapat dilihat pada tabel 5 dan Gambar 21 hingga 25.

Tabel 5 Analisis Statistik Mann-Whitney dari Rerata Skor Fibrosis

\begin{tabular}{cccccc}
\hline Kelompok & Kontrol (-) & PTL & P1 & P2 & P3 \\
\hline Kontrol (-) & & $0,026^{*}$ & $0,180^{\mathrm{ns}}$ & $0,394^{\mathrm{ns}}$ & $0,093^{\mathrm{ns}}$ \\
PTL & & & $0,180^{\mathrm{ns}}$ & $0,093^{\mathrm{ns}}$ & $0,394^{\mathrm{ns}}$ \\
P1 & & & & $0,699^{\mathrm{ns}}$ & $0,699^{\mathrm{ns}}$ \\
P2 & & & & & $0,394^{\mathrm{ns}}$ \\
P3 & & & & & \\
\hline
\end{tabular}

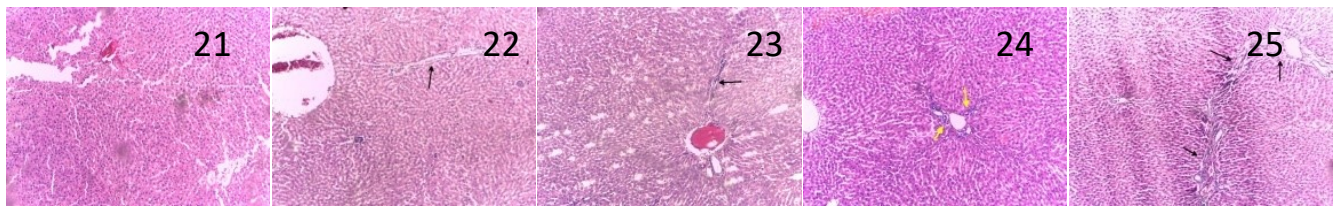

Gambar 21 Hepar dari kelompok kontrol negatif tidak menunjukkan adanya gambaran fibrosis (100x).

Gambar 22 Hepar dari kelompok kontrol PTL menunjukkan gambaran fibrosis.Tanda panah hitam menunjukkan adanya fibrosis pada daerah perisinusoidal dan portal atau periportal (100x).

Gambar 23 Hepar dari kelompok PTL+200 mg menunjukkan adanya gambaran fibrosis. Tanda panah hitam menunjukkan adanya fibrosis pada daerah periportal (100x).

Gambar 24 Hepar dari kelompok PTL +400 mg menunjukkan adanya gambaran fibrosis. Tanda panah kuning menunjukkan adanya fibrosis pada daerah perisinusoidal dan portal atau periportal (100x)

Gambar 25 Hepar dari kelompok PTL+600 mg menunjukkan adanya gambaran fibrosis. Tanda panah hitam menunjukkan adanya bridging fibrosis, dimana fibrosis terjadi antara satu portal area ke portal area lainnya (100x). 


\section{Hasil pemeriksaan kadar serum ALTdan GGT}

Dari hasil pemeriksaan serum tikus Wistaryang dilakukan pada hari ke 22 dan 50, didapatkan bahwa P1 (EEKR $200 \mathrm{mg} / \mathrm{KgBB} / \mathrm{hr}$ ) menurunkan secara bermakna kadar enzim ALT (Gambar 26) tetapi tidak menurunkan secara bermakna kadar enzim GGT(Gambar 27).Sedangkan pada $\mathrm{P} 2$ (EEKR $400 \mathrm{mg} / \mathrm{KgBB} / \mathrm{hr}$ ) menurunkan secara bermakna kadar enzim ALT dan GGT. Pemberian EEKR $600 \mathrm{mg} / \mathrm{KgBB} / \mathrm{hr}$ (P3) menurunkan kadar enzim ALT dan GGT secara bermakna serta memiliki potensi yang sama dengan EEKRdosis $400 \mathrm{mg} / \mathrm{KgBB} / \mathrm{hr}$.

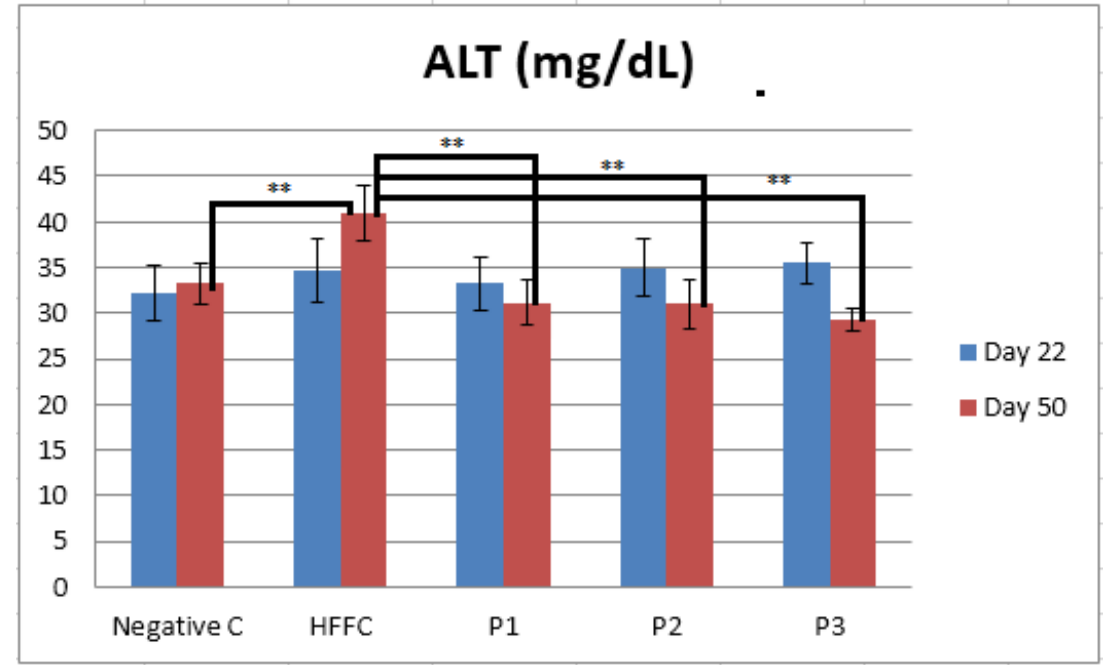

\section{Gambar 26 Hasil Analisis Rerata Kadar ALT Tikus setelah Perlakuan22 dan 50 hari}

\section{Keterangan}

1 Kontrol Negatif $(\mathrm{KN})$ : Pelet Standar

2 HFFC = PTL: Pakan Tinggi Lemak

3 P1: PTLdanEEKR $200 \mathrm{mg} / \mathrm{KgBB}$

4 P2: PTLdanEEKR $400 \mathrm{mg} / \mathrm{KgBB}$

5 P3: PTLdanEEKR $600 \mathrm{mg} / \mathrm{KgBB}$ 


\section{Research Article}

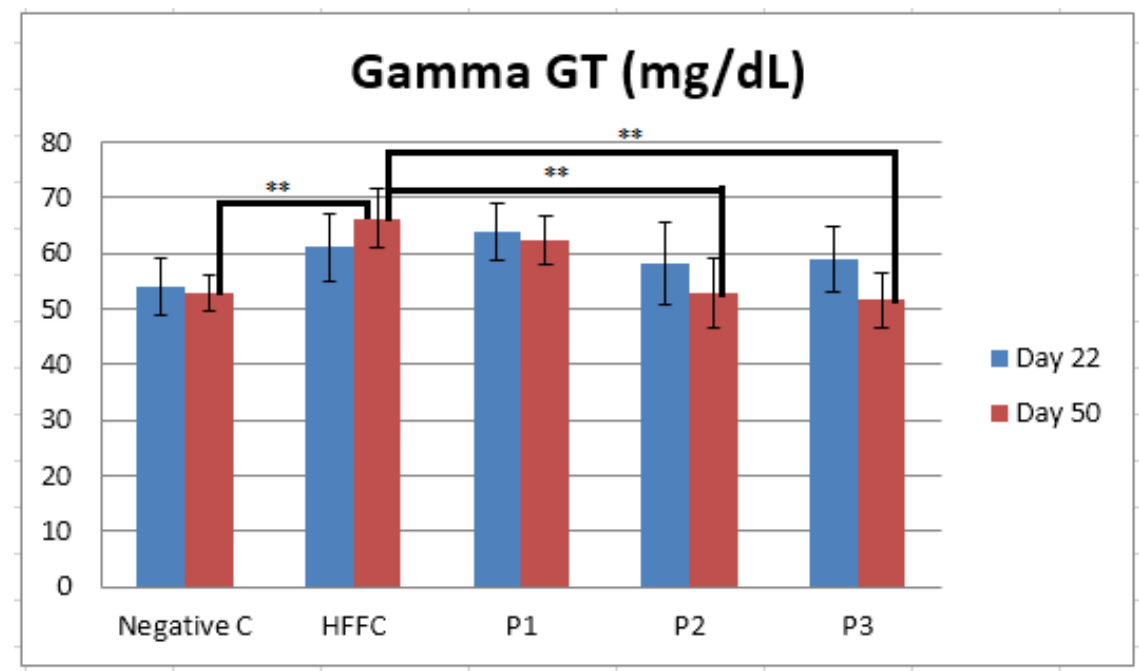

\section{Gambar 27 Hasil Analisis Rerata Kadar GGT Tikus setelah Perlakuan 22 dan 50 hari}

\section{Keterangan}

$$
\begin{aligned}
& \text { Kontrol Negatif }(\mathrm{KN}) \text { : Pelet Standar } \\
& \text { HFFC = PTL: Pakan Tinggi Lemak } \\
& \text { P1: PTLdanEEKR } 200 \mathrm{mg} / \mathrm{KgBB} \\
& \text { P2: PTLdanEEKR } 400 \mathrm{mg} / \mathrm{KgBB} \\
& \text { P3: PTLdanEEKR } 600 \mathrm{mg} / \mathrm{KgBB}
\end{aligned}
$$

\section{Diskusi}

Pemberian EEKRdosis200 mg/KgBB/hr menunjukkan penurunan skor bengkak keruh, sedangkan EEKR dosis 200, 400, $600 \mathrm{mg} / \mathrm{KgBB} / \mathrm{hr}$ menurunkan skor steatosis hati pada tikus yang diberi pakan tinggi lemak selama 50 hari. Pada kelompok kontrol yang hanya diberi PTL didapatkan gambaran bengkak keruh akibat banyaknya deposit lemak sehingga menyebabkan kerusakan sel hati. Obesitas dan asupan lemak berlebih menjadi faktor risiko utama dari penyakit NAFLD. Bentuk awal dan tersering dari NAFLD adalah simple steatosis. Steatosis adalah adanya deposit trigliserida dalam sitoplasma sebagai makrovesikuler atau mikrovesikuler lebih dari 5\% total hepatosit. ${ }^{11}$ Deposit lemak ini merusak mitokondria sehingga menyebabkan kekurangan ATP. Kekurangan ATP menyebabkan terjadi gangguan dari sodium pump sehingga air dari dari ekstraseluler masuk ke dalam sel hepar. ${ }^{21}$

Penelitian lain menunjukkan bahwa Rosella mempunyai efek pencegahan terhadap steatosis namun bersifat dose dependent, yaitu dosis $300 \mathrm{mg} / \mathrm{kgBB} / \mathrm{hari}$ menurunkan skor histopatologis steatosis, sedangkan dosis yang lebih rendah yaitu $150 \mathrm{mg} / \mathrm{kgBB} / \mathrm{hari}$ tidak mempunyai efek tersebut. ${ }^{18}$ Hasil pengamatan gambaran peradangan lobular menunjukkan kelompok kontrol PTL dan kelompok kontrol negatif menunjukkan perbedaan yang signifikan. Induksi lemak yang berlebihan dapat memicu respon inflamasi. Rosella mempunyai fungsi 


\section{Research Article}

imunomodulator yang baik, yaitu mampu memperbaiki sistem imun dengan cara stimulasi (imunostimulan) atau menekan/menormalkan reaksi imun yang abormal (imunodepresan). Pada pemberian EEKR dosis $200 \mathrm{mg}, 400 \mathrm{mg}$, dan $600 \mathrm{mg} / \mathrm{kgBB} / \mathrm{hr}$ terjadipenekanan reaksi imun akibat induksi lemak yang berlebihan. Berdasarkan penelitian yang dilakukan oleh Nurkhasanah et al disebutkan bahwa Rosella mempunyai efek imunomodulator, mampu meningkatkan ekpresi dari IL-10 dan IL-14. Sitokin IL-10 merupakan mediator yang berfungsi sebagai penghambat aktivitas respon imun terutama pada makrofag.Sitokin IL-14 berfungsi untuk mengontrol proliferasi dan pertumbuhan dari sel B, molekul ini disebut juga taxilin. Sitokin IL14 berperan untuk menginduksi proliferasi sel $\mathrm{B}$, tetapi efeknya menghambat produksi antibodi. $^{22}$

Gambaran degenerasi balon terjadi pada pemberian EEKR $600 \mathrm{mg} / \mathrm{kgBB} / \mathrm{hr}$. Degenerasi balon adalah suatu kerusakan hepatoseluler lanjut yang irreversible. Gambaran degenerasi balon ini hanya terdapat pada EEKR dosis yang paling tinggi dalam penelitian ini, yaitu $600 \mathrm{mg} / \mathrm{kg}$ BB/hari. Roselladapat meningkatkan kesehatan hati dan membantu mengurangi perlemakan hati pada pasien obesitas, akan tetapi pada jumlah ekstrim atau dosis yang sangat tinggi dapat menjadi toksik bagi organ hati. ${ }^{23}$ Sesungguhnya dosis toksik akut untuk Hibiscus sabdariffa adalah cukup tinggi, yaitu di atas $5.000 \mathrm{mg} / \mathrm{kgBB}$. Hasil penelitian Sireeratawong dkk, membuktikan bahwa pada dosis tinggi tersebut Rosella tidak menyebabkan kematian, tidak tampak tanda-tanda toksisitas atau perubahan perilaku atau aktivitas fisiologis hewan coba dibandingkan dengan kelompok kontrol; bahkan pada uji toksisitas kronik pemberian ekstrak air Rosella dosis 50, 100 and $200 \mathrm{mg} / \mathrm{kgBB}$ selama 270 hari, sama sekali tidak menunjukkan gejala toksik pada tikus. $^{24}$

Hasil pengamatan gambaran fibrosis didapatkan pada kelompok kontrol PTL, dan semua dosis pemberian EEKR. Jaringan fibrosis terbentuk pada kelompok kontrol PTL sebagai respons terhadap peradangan atau kerusakan hati akibat induksi lemak yang berlebihan. Jaringan fibrosis yang terbentuk pada kelompok pemberian EEKR 200mg sedikit rendah, terlihat dari skor analisis histopatologisnya bila dibandingkan dengan kelompok kontrol PTL, namun tidak berbeda signifikan secara statistik. Pada pemberianEEKR $400 \mathrm{mg}$ dan 600 $\mathrm{mg} / \mathrm{kgBB} / \mathrm{hrjaringan}$ fibrosis yang terbentuk sebagai respon kerusakan hepatoseluler pada keadaan stres oksidatif akibat PTL. Menurut penelitian Kanuriet al., tikus yang diberi asupan pakan PTL selama 9 minggu, preparat histopatologis heparnya menunjukkan steatohepatitis dengan gambaran fibrosis. ${ }^{11}$ Dalam studi ini diberikan PTL hanya selama 50 hari, kurang lebih 8 minggu.Hal ini menjadi salah satu keterbatasan penelitian. 


\section{Research Article}

Pada pemeriksaan GGT, kelompok P1 tidak berbeda secara signifikan dengan kelompok PTL. Hal ini menunjukkan bahwa pemberian EEKR 200 mg / KgBB tidak memiliki efek untuk menurunkan kadar enzim GGT. Kelompok PTL berbeda signifikan dengan kelompok kontrol negatif, P2 dan P3 . Hasil pemeriksaan GGT menunjukkan bahwa kontrol PTL $(66,17) \pm 5,27 \mathrm{mg} / \mathrm{dL})$ berbeda signifikan dengan kelompok kontrol negatif $(52,83 \pm 3,19$ $\mathrm{mg} / \mathrm{dL}), \mathrm{P} 2(52,67 \pm 6,31 \mathrm{mg} / \mathrm{dL})$, dan P3 (51,50 \pm 5,09 mg / dL). Kelompok P2 menunjukkan kadar GGT paling rendah, maka dosis EEKR 400mg dipertimbangkan sebagai dosis efektif yang potensial untuk menurunkan kadar GGT.

Pada penelitian ini, pemberian EEKR $200 \mathrm{mg} / \mathrm{KgBB} / \mathrm{hr}$ menurunkan secara bermakna kadar enzim ALT. Hasil ini sejalan dengan studi Ali BH et al dan Marty, di mana Ali BH menggunakan ekstrak air Hibiscus sabdariffa dosis $200 \mathrm{mg} / \mathrm{kgBB}$ dan sedangkan Marty menggunakan dosis $100 \mathrm{mg} / \mathrm{kgBB}$ dua kali sehari untuk menurunkan tingkat enzim hati dan mengurangi kerusakan hati. ${ }^{15,17}$ Hipotesis mekanisme kerja Rosella dalam menurunkan enzim ALT adalah melalui aktivitas antioksidan yang mengurangi stres oksidatif dan disfungsi mitokondria dengan penurunan Baz dan tBID di hati, sehingga terjadi penurunan enzim hati seperti AST, ALT dan Alkali Phosphatase (ALP). ${ }^{19}$

\section{Simpulan}

Pemberian EEKR dosis $200 \mathrm{mg} / \mathrm{KgBB} / \mathrm{hr}$ menurunkan skor bengkak keruh dan steatosis, EEKR dosis 400 dan $600 \mathrm{mg} / \mathrm{KgBB} / \mathrm{hr}$ menurunkan kadar ALT dan GGT pada tikus Wistar jantan yang diinduksi oleh PTL. Mempertimbangkan efektivitas dan keamanannya, rekomendasi dosis efektif dari ekstrak etanol kelopak Rosella untuk penyakit hati berdasarkan gambaran histopatologis hati, ALT dan GGT pada tikus Wistar jantan yang diinduksi oleh PTL adalah dosis $200-400 \mathrm{mg} / \mathrm{KgBB} / \mathrm{hr}$.

\section{Daftar Pustaka}

1. Ajiboye TO, Salawu NA, Yakubu MT, Oladiji AT, Akanji MA, Okogun JI. Antioxidant and drug detoxification potentials of Hibiscus sabdariffa anthocyanin extract. Drug Chem Toxicol. 2011; 34:109-15.

2. Ramadhani MR, Bachri MS, Widyaningsih W. Effects of ethanolic extract of arrowroot tubers (maranta arundinacea 1.) on the level of MDA, SGPT and SGOT in ethanol induced rats. Indones J Med Heal. 2017;8(1):10-8.

3. Adeyemi DO, Ukwenya VO, Obuotor EM, Adewole SO. Anti-hepatotoxic activities of Hibiscus sabdariffa L. In animal model of streptozotocin diabetes-induced liver damage. BMC Complement Altern Med. 2014; 14(1):277

4. Ahmad-Raus R, Jamal P, Mohd-Isa ES. Hibiscus sabdariffa aqueous extracts prevents progression of acute liver injury induced by acetaminophen. Pertanika J Trop Agric Sci. 2012;35(3):513-20.

5. Ahmed GS, Hassan EM, Khalifa DM. Hepatoprotective effect of aqueous extracts of some medicinal plant mixtures on CCl4-induced liver toxicity. IOSR J Pharm Biol Sci Ver I. 2017; 12(01):43-52. 


\section{Research Article}

6. Li S, Tan HY, Wang N, Zhang ZJ, Lao L, Wong CW, et al. The role of oxidative stress and antioxidants in liver diseases. Int J Mol Sci. 2015; 16:26087-124.

7. Putra YA, Ghozali A. Pengaruh pemberian Phyllanthus niruri terhadap perlemakan hati pada Rattus norvegicus dengan dislipidemia [Internet]. Universitas Gadjah Mada; 2015. Available from: http://etd.repository.ugm.ac.id/index.php?mod=opac\&sub=Opac\&act=view\&typ=html\&opac_page=3\&cari=\&fir $\mathrm{st}=1 \&$ op=opac\&obyek_id=4\&srcjudul=histopatologi + hati\&lokasi $=1 \&$ link $=1 \&$ jenis_id=\&cari $=$

8. Takahashi Y, Fukusato T. Histopathology of nonalcoholic fatty liver disease/nonalcoholic steatohepatitis. World J Gastroenterol. 2014; 20(42): 15539-48.

9. Brunt EM, Tiniakos DG. Histopathology of nonalcoholic fatty liver disease. World J Gastroenterol. 2010;16(42): 5286-96.

10. Kleiner DE, Brunt EM, Van Natta M, Behling C, Contos MJ, Cummings OW, et al. Design and validation of a histological scoring system for nonalcoholic fatty liver disease. Hepatology. 2005; 41(6):1313-21.

11. Kanuri G, Bergheim I. In vitro and in vivo models of non-alcoholic fatty liver disease (NAFLD). Int J MolSci. 2013.14(6): 11963-80.

12. Kim WR, Flamm SL, Di Bisceglie AM, Bodenheimer HC. Serum activity of alanine aminotransferase (ALT) as an indicator of health and disease. Hepatology. 2008.

13. Sosrosumihardjo, Rustadi, Giantini A. Buku Ajar Ilmu Penyakit Hati. Jakarta : Jayabadi,2007. p. 21.: Jaya Abadi; 2007. p 21 .

14. Bedogni G, Bellentani S, Miglioli L, Masutti F, Passalacqua M, Castiglione A, et al. The fatty liver index: A simple and accurate predictorof hepatic steatosis in the general population. BMC Gastroenterol. 2006; 6:33.

15. AliBH, Mousa HM, Mougy SE. The effect of a water extract and anthocyanins of Hibiscus sabdariffa L on paracetamol induced hepatotoxicity in rats. Phytother Res. 2003;17:56-9.

16. Sujono, Tanti Azizah; Widiatmoko, Yudhistira Wahyu; Karuniawati H. Efek infusa bunga Rosella (Hibiscus sabdariffa) pada serum glutamate piruvat transaminase tikus yang diinduksi parasetamol dosis toksik. Univ Muhammadiyah Surakarta [Internet]. 2012;13(2). Available from: http://hdl.handle.net/11617/3371

17. Marty AT. PDR for Herbal Medicines. JAMA J Am Med Assoc. 1999;280:1569-75

18. Husen IR,Sastramihardja HS. Efek hepatoprotektif Rosella (Hibiscus sabdariffa L.) pada tikus model hepatitis. 2012; Available from: https://www.researchgate.net/publication/274937522_Efek_Hepatoprotektif_Rosella_Hibiscus_sabdariffa_L_pad a_Tikus_Model_Hepatitis

19. Da-Costa-Rocha I, Bonnlaender B, Sievers H, Pischel I, Heinrich M. Hibiscus sabdariffa L. - A phytochemical and pharmacological review. Food Chemistry. 2014.165:424-43.

20. Kelompok Kerja Ilmiah. Penapisan farmakologi pengujian fitokimia dan pengujian klinik. Jakarta: Yayasan Pengembangan Obat Bahan Alam Phyto Medica. Departemen Kesehatan RI; 1993.

21. Plumeriastuti H. Pengaruh borax terhadap gambaran histopatologi duodenum tikus putih (Rattus norvegicus). Vet Med 6, 83-160. 2013;6:83-160.

22. Nurkhasanah. The effect of rosella (Hibiscus sabdariffa L) treatment on IL-10 and IL-14 secretion on dimethylbenz (A) anthracene (DMBA) induced rat. Int J Pharm Pharm Sci. 2015;7(4)

23. Uhrotun UF, Rasjad ISS. Ekstrak Rosela menurunkan perlemakan dan ekspresi ADMA hepar akibat diet aterogenik pada tikus. J Kedokt Brawijaya. 2014;28(1):6-10.

24. Sireeratawong S,Itharat A, Khonsung P, Lertprasertsuke N, Jaijoy K. Toxicity studies of thewater extract from the calyces of Hibiscus Sabdariffa L. in rats. Afr J Tradit Complement Altern Med. 2013;10(4):122-7. 